\title{
経験想起法による客観的品質特性と主観的品質特性、 および意味性の検討
}

\author{
○黒須正明 ${ }^{1}$ \\ $\left({ }^{1}\right.$ 放送大学) \\ キーワード : 経験工学、品質特性、意味性
}

\begin{abstract}
Objective Quality Characteristics, Subjective Quality Characteristics and Meaningfulness
Analyzed by the Experience-Remembrance Method

Masaaki KUROSU ${ }^{1}$

( ${ }^{1}$ The Open University of Japan)
\end{abstract}

Key Words: experience engineering, quality characteristics, meaningfulness

目 的

発表者は、人間中心設計(HCD: Human Centered Design) が対象とする人工物 すなわち製品やシステムサービ スについてそれらをユーザや顧客にとって意味あるも のにする設計開発の手法として、ビジネスマイクロエス ノグラフィの手法を開発·整備することを目標として現 在研究を進めている ビジネスマイクロエスノグラフィ は近年ビジネス領域で使われているビジネスエスノグ ラフィに学問的な骨格を与えるために民族学や質的心 理学の分野で発展してきたマイクロエスノグラフィ

(LeCompte and Preissle 1993, 箕浦 2009))の考え方をより 実践的な方向に発展させて構成するものである。

ビジネスマイクロエスノグラフィでは、ハードウェアやソ フトウェア、ヒューマンウェア(サービス)などの人工物に意 味があるかどうか、すなわち意味性 (meaningfulness)を重視 する。意味性とは、当該の人工物が ユーザや顧客の生活 現場等で真に有意味であり 有意義なものかということ である。

現在、産業界に広く普及したユーザエクスペリエン ス(UX: User Experience)の概念をサービスにまで拡張し た経験工学(experience engineering)では、ユーザビリテ イや機能性などの客観的品質特性と、審美性や愛着感 などの主観的品質特性に併せて、意味性を重視してい る。意味性の高い人工物であれば、ユーザの生活の質 を高め、満足感を与えることになり、結果的に長期間 利用されることになるだろうと考えられる

意味性についてはこれまでにもある程度、個別の事 例を収集してきたが 多数の事例を分類し意味性の下 位次元を見つけそれにもとづいた意味性の再定義を行 ったりするためには、更に事例を集める必要がある。そ のため、今回は発表者の提案する経験想起法(experience remembrance method)によって事例収集を行う

\section{方 法}

本研究で用いる経験想起法は、その概念的枠組みとし て品質工学における狩野モデル(1984)を用いている。狩 野モデルでは、当たり前品質と魅力的品質を区別して いるが、前者は充足されていて当然の品質であること から客観的品質特性に、また後者は充足されていれば 望ましいといえる品質であることから主観的品質特性 に対応する概念といえる。
経験想起法の具体的な手順としては、調査対象とす る人工物に関するこれまでの経験、いいかえれば購入 や入手する以前の期待から始まり、購入・入手時点で の印象、その後の短期的な評価、さらに現在に至るま での長期的な評価を含む時系列的な全体経験、を想起 してもらい、それを評価させる。すなわち、まず両品 質特性に関する評価を求め、さらに全体的評価(意味性) に関する評価がポジティブなものとネガティブなもの か(当然ニュートラルなものも含まれる)を評価させる。 併せてその経験の当人にとっての意味について聞き取 りを行い 記録するものである。さらにポジティブない しネガティブな経験については、何故その経験に意味 があるのか、あるいは無いのかを詳細に聞き取り、分 析する。

なお、一般の聞き取り方法では 具体的な場面ごとの 経験に関する情報が得にくいと予想されるそこで経験 想起法では 想起のための手がかりとして様々な経験の 場面を想定した場面リストを提示しその各々について ポジティブな経験やネガティブな経験を想起してもら うそのリスト項目は、たとえば「携帯で家族に帰宅の 遅れを伝えようとした時」「病院で順番待ちをしている 時」のような場面記述である

この経験想起法を用いると、従来のマイクロエスノグラフ イのように、様々な経験に関するヒアリングを行った上で問 題点に焦点化するよりも、効率的に人工物に関する問題を抽 出することができ、産業的な目的における人工物(製品やシス テムやサービス)の改善や向上、あるいは新規な人工物の企画 にとって、戦略的なツールとなることが期待される。

\section{結 果. 考 察}

この原稿作成時点では、方法の精緻化と場面記述の作成を 行っており、実際に適用した結果については、大会において 報告する。

\section{引用文献}

LeCompte, M.D. and Preissle, J. (1993) "Ethnography and Qualitative Design in Educational Research - Second Edition" Academic Press

箕浦康子 (2009) “フィールドワークの技法と実際 II 分析 • 解釈編”ミネルヴァ書房

狩野紀昭、瀬楽信彦、高橋文夫、辻新一 (1984) "魅力的品質 と当たり前品質" 品質工学, 14(2), pp. 39-48 